ENCYCLOPEDDIE Encyclopédie berbère

BERBERE

$24 \mid 2001$

24 | Ida - Issamadanen

\title{
Iklan(voir Akli)
}

\section{(2) OpenEdition}

1 Journals

Édition électronique

URL : http://journals.openedition.org/encyclopedieberbere/1559

DOI : 10.4000/encyclopedieberbere.1559

ISSN : 2262-7197

Éditeur

Peeters Publishers

\section{Édition imprimée}

Date de publication : 1 octobre 2001

Pagination : 3684

ISBN : 2-7449-0207-1

ISSN : 1015-7344

Référence électronique

« Iklan(voir Akli) », Encyclopédie berbère [En ligne], 24 | 2001, document I45, mis en ligne le 01 juin 2011, consulté le 25 septembre 2020. URL : http://journals.openedition.org/encyclopedieberbere/1559

DOI : https://doi.org/10.4000/encyclopedieberbere.1559

Ce document a été généré automatiquement le 25 septembre 2020

(C) Tous droits réservés 
Iklan(voir Akli) 